Tropical Journal of Pharmaceutical Research, June 2008; 7 (2): 987-994

(C) Pharmacotherapy Group,

Faculty of Pharmacy, University of Benin

Benin City, Nigeria.

All rights reserved.

Research Article

Available online at http://www.tjpr.org

\title{
Formulation of the extract of the stem bark of Alstonia boonei as tablet dosage form
}

\section{SO Majekodunmi ${ }^{\mathrm{a}}$, OA Adegoke ${ }^{\mathrm{b}}$ and OA Odeku ${ }^{\mathrm{a} \star}$}

${ }^{a}$ Department of Pharmaceutics and Industrial Pharmacy, and ${ }^{b}$ Department of Pharmaceutical Chemistry, Faculty of Pharmacy, University of Ibadan, Ibadan, Nigeria.

\begin{abstract}
Purpose: To formulate the extracts of the stem bark of Alstonia boonei, an important antimalarial herb, into tablet dosage form.

Methods: Tablets were formulated using direct compression and wet granulation methods. The mechanical properties of the tablets were assessed using crushing strength and friability and the crushing strength:friability ratio (CSFR) while drug release properties were evaluated using disintegration and dissolution times.

Results: There were statistically significant $(p<0.01)$ differences in the CSFR values and drug release properties of $A$. boonei tablets prepared by both methods. The differences depended on the type and concentration of excipient and binder employed in the formulation.

Conclusions: The method of preparation of the $A$. boonei tablets needs to be carefully selected to ensure the production of tablets with adequate bond strength to withstand the rigours of handling and at the same time release the active compound (s) for biological action.
\end{abstract}

Keywords: Alstonia boonei, excipient, binder, tablets, mechanical properties, drug release properties 


\section{INTRODUCTION}

Alstonia boonei De Wild belongs to the family called Apocynaceaee which consists of about 50 species widely distributed in the continents of Africa, Asia and America ${ }^{1-3}$. Alstonia boonei, known as Ahun in Yoruba, Egbu-ora in Igbo, Ukhu in Edo and Ukpukunu in Urhobo, is a widely distributed plant in the lowlands and rain-forest areas of Nigeria. Parts of the plant are employed for the treatment of a variety of ailments in Africa and the stem bark has been listed in the African Pharmacopoeia as an anti-malarial drug. The stem bark of $A$. boonei is used in traditional medicine to treat fever, painful micturition, insomnia, chronic diarrhea, rheumatic pains, as anti-venom for snake bites and in the treatment of arrow poisoning ${ }^{4-7}$. The chemical constituents include alkaloids, triterpenoids and steroids ${ }^{2,4}$. Over $90 \%$ of the isolated chemical constituents are alkaloids many of which are the indole types ${ }^{2,4}$. The major alkaloids are echitamine and echitamidine. In vitro antiplasmodial activity of the alkaloids against both drug sensitive and resistant strains of $P$. falciparum ${ }^{8}$ and in vivo activity against $P$. berghei in mice ${ }^{9,10}$ have been reported. In another trial, the anti-inflammatory properties of the alcoholic extract $A$. boonei in rat hind paw edema has been used to justify its use in herbal medicine for the treatment of rheumatic and muscular pains ${ }^{11,12}$.

In spite of their efficacy, herbal medicinal products have been widely criticized due to lack of standardization and poor-quality presentation. In traditional medicine, the stem bark of $A$. boonei is usually soaked in water and unspecified quantities of the decoction are ingested. However, to improve patient compliance and acceptance, there is need to formulate the stem bark of $A$. boonei into tablet dosage form ${ }^{13}$. Thus, the aim of the present study is to produce conventional tablets of the extracts of the stem bark of $A$. boonei for oral administration using direct compression and wet granulation methods to determine the more suitable method for the preparation of the tablets. The mechanical properties of the tablets were assessed using crushing strength and friability and the crushing strength friability ratio (CSFR) while the drug release properties were assessed using the disintegration and dissolution times.

\section{MATERIALS AND METHODS}

The materials used were Emcompress ${ }^{\circledR}$ (dicalcium phosphate, Mendell Co Ltd., Surrey, UK), Avicel ${ }^{\circledR}$ PH 102 (FMC International Co. Cork, Ireland), lactose (DMV, Veghel, Netherlands), polyvinylpyrrolidone, PVP average molecular weight 360,000 (Aldrich Chemicals Co Limited, Gillingham, Dorset, UK), corn starch B.P (BDH Chemicals, Poole, UK), magnesium stearate (Hopkin and Williams, Chadwell, Health, Essex, UK), and absolute ethanol 96\% (BDH Chemicals, Poole, UK).

The stem bark of Alstonia boonei was purchased from the herbal wholesalers at Oyingbo market, Lagos, Nigeria and authenticated at the Forestry Research Institute of Nigeria, Ibadan, Nigeria (Voucher FHI 107254).

\section{Extraction of the Powdered Stem Bark}

The stem bark was washed and then dried in a GallenKamp Moisture Extraction Oven (Model: BS 250 GallenKamp Co., UK) at $40^{\circ} \mathrm{C}$ for four days. The dried bark was ground to a coarse powder using a laboratory mill (Kenwood UK Ltd, Hertfordshire UK). $6 \mathrm{Kg}$ of the powdered sample was exhaustively extracted three times with $10 \mathrm{~L}$ absolute ethanol for $48 \mathrm{~h}$ by maceration. The solvent was removed at $30^{\circ} \mathrm{C}$ under reduced pressure and then evaporated to dryness. The dried extract was reduced to powder using a laboratory mill and then sieved with a $120 \mu \mathrm{m}$ mesh sieve. The yield was $6 \% \mathrm{w} / \mathrm{w}$.

\section{Preparation of Powder Mixtures for Direct Compression}

Fifty gram batches consisting of $A$. boonei extract and Avicel ${ }^{\circledR}$ or Emcompress ${ }^{\circledR}$ in a ratio of $1: 9$ and 1:4 drug: excipient were thoroughly mixed and stored in airtight containers. 
Table 1: Crushing strength, friability, crushing strength-friability ratio of Alstonia boonei tablets prepared by direct compression and wet granulation (mean $\pm S D, n=4$ )

\begin{tabular}{|c|c|c|c|c|c|}
\hline \multirow{2}{*}{$\begin{array}{l}\text { Compression } \\
\text { Pressure } \\
\text { (KN) }\end{array}$} & & & \multicolumn{3}{|c|}{ Direct compression } \\
\hline & Diluent & $\begin{array}{c}\text { Drug - Diluent } \\
\text { Ratio }\end{array}$ & $\begin{array}{c}\text { Crushing } \\
\text { Strength( N) }\end{array}$ & $\begin{array}{c}\text { Friability } \\
\text { (\%) }\end{array}$ & CSFR \\
\hline 5 & & & $55.92 \pm 1.30$ & $0.58 \pm 0.01$ & 96.41 \\
\hline 10 & & & $63.77 \pm 1.48$ & $0.53 \pm 0.02$ & 120.32 \\
\hline 5 & Lactose & $1: 4$ & $33.65 \pm 0.08$ & $1.27 \pm 0.02$ & 26.50 \\
\hline 10 & & & $64.06 \pm 0.01$ & $0.87 \pm 0.03$ & 73.63 \\
\hline 5 & & $1: 9$ & $46.79 \pm 1.84$ & $1.39 \pm 0.01$ & 33.66 \\
\hline 10 & & & $62.49 \pm 0.87$ & $1.18 \pm 0.02$ & 52.96 \\
\hline 5 & Avicel ${ }^{\circledR} \mathrm{PH} 102$ & $1: 4$ & $178.54 \pm 1.91$ & $0.43 \pm 0.01$ & 415.21 \\
\hline 10 & & & $188.35 \pm 1.85$ & $0.39 \pm 0.01$ & 482.20 \\
\hline 5 & & $1: 9$ & $192.28 \pm 0.99$ & $0.44 \pm 0.01$ & 437.00 \\
\hline 10 & & & $199.14 \pm 1.71$ & $0.40 \pm 0.02$ & 497.65 \\
\hline 5 & Emcompress $^{\circledR}$ & $1: 4$ & $34.34 \pm 2.33$ & $2.05 \pm 0.02$ & 16.75 \\
\hline 10 & & & $47.09 \pm 2.54$ & $1.43 \pm 0.07$ & 32.93 \\
\hline 5 & & $1: 9$ & $45.13 \pm 1.32$ & $1.99 \pm 0.03$ & 22.68 \\
\hline 10 & & & $51.99 \pm 5.63$ & $1.63 \pm 0.02$ & 31.90 \\
\hline
\end{tabular}

\begin{tabular}{|c|c|c|c|c|}
\hline \multirow[b]{2}{*}{ Binder } & \multirow[b]{2}{*}{$\begin{array}{l}\text { Binder concentration } \\
\qquad(\% w / w)\end{array}$} & \multicolumn{3}{|c|}{ Wet granulation } \\
\hline & & $\begin{array}{c}\text { Crushing } \\
\text { Strength( N) }\end{array}$ & $\begin{array}{c}\text { Friability } \\
\text { (\%) }\end{array}$ & CSFR \\
\hline \multirow[t]{4}{*}{ PVP } & 1 & $101.04 \pm 1.23$ & $0.62 \pm 0.01$ & 162.97 \\
\hline & & $108.89 \pm 1.18$ & $0.57 \pm 0.01$ & 191.04 \\
\hline & 4 & $161.87 \pm 1.09$ & $0.51 \pm 0.01$ & 317.39 \\
\hline & & $178.54 \pm 0.68$ & $0.41 \pm 0.02$ & 435.46 \\
\hline \multirow[t]{4}{*}{ Gelatin } & 1 & $94.18 \pm 0.52$ & $0.66 \pm 0.02$ & 142.70 \\
\hline & & $120.66 \pm 0.55$ & $0.53 \pm 0.01$ & 227.66 \\
\hline & 4 & $116.74 \pm 0.63$ & $0.60 \pm 0.02$ & 194.57 \\
\hline & & $172.66 \pm 0.59$ & $0.51 \pm 0.03$ & 338.55 \\
\hline \multirow[t]{4}{*}{ Cornstarch } & 1 & $38.26 \pm 0.50$ & $0.87 \pm 0.02$ & 43.98 \\
\hline & & $47.09 \pm 0.67$ & $0.69 \pm 0.01$ & 68.25 \\
\hline & 4 & $81.42 \pm 0.52$ & $0.67 \pm 0.03$ & 121.52 \\
\hline & & $114.78 \pm 0.59$ & $0.55 \pm 0.02$ & 208.69 \\
\hline
\end{tabular}




\section{Preparation of Granules}

Batches $(200 \mathrm{~g})$ of a basic formula of $A$. boonei extract $(10$ or $20 \% \mathrm{w} / \mathrm{w})$, lactose $(70$ or $80 \% \mathrm{w} / \mathrm{w}$ ) and corn starch $(10 \% \mathrm{w} / \mathrm{w})$ were dry-mixed for five minutes in a Kenwood planetary mixer and then moistened with $1 \% \mathrm{w} / \mathrm{w}$ or $4 \% \mathrm{w} / \mathrm{w}$ concentration of binder solution (PVP or corn starch mucilage). The wet masses were granulated by passing them manually through a No. 12 mesh sieve $(1,400 \mu \mathrm{m})$ (BS 410, Endecotts Ltd, London, UK), dried in hot air oven for 18 hours at $50^{\circ} \mathrm{C}$, and then resieved through a No. 16 mesh size $(1,000 \mu \mathrm{m})$. The granules were stored in airtight containers.

The moisture contents of the powder and granule formulations were determined with an Ohaus moisture balance (Ohaus Scale Corporation, USA) and found to be between 1.1 and $1.3 \% \mathrm{w} / \mathrm{w}$.

\section{Preparation of Tablets}

Tablets (final weight - $500 \mathrm{mg}$ ) were prepared from the powder mixture and granules (500$1000 \mu \mathrm{m}$ size fractions) by compressing the materials for thirty seconds with predetermined loads of 5 and $10 \mathrm{KN}$ using a Carver Hydraulic Hand Press (Model C, Carver Inc, Menomonee Falls, WI, USA). Before each compression, the die $(10.5 \mathrm{~mm}$ diameter) and the flat-faced punches were lubricated with a $2 \% \mathrm{w} / \mathrm{w}$ dispersion of magnesium stearate in ethanol: ether (1:1 solution). After ejection, the tablets were stored over silica gel for 24 hours to allow hardening and elastic recovery.

\section{Crushing Strength and Friability Tests}

The load $(\mathrm{N})$ required to diametrically break each tablet (crushing strength, CS) was determined at room temperature using a PTB 301 crushing strength tester (Pharmatest, Switzerland). The friability $(F)$ of the tablets were determined using a friabilator (Model TF 2D, Scientific Equipment Ltd., Bombay, India) operated at 25 revolutions per minute for 4 minutes.

\section{Disintegration Test}

The disintegration times (DT) of the tablets were determined in distilled water at $37 \pm 0.5^{\circ} \mathrm{C}$ using an Erweka disintegration testing apparatus (Model: Copley ZT2, Erweka Apparatebau GMBH, Heusenstamm, Germany).

\section{Determination of absorption maxima for Alstonia boonei stems bark extract}

$1 \mathrm{~g}$ of the extract was placed in a $100 \mathrm{ml}$ flask and $50 \mathrm{~mL}$ of $0.1 \mathrm{M} \mathrm{HCl}$ was added. The flask was agitated in a shaker for about $1 \mathrm{hr}$, and then filtered through a Whatman filter paper. The absorption spectrum of the solution of the extract was recorded using a UV spectrophotometer (Model Cintra 6, Type GBC UV-Visible, GBC, Scientific Equipment Ltd, Victoria, Australia) and the wavelength for maximum absorption was determined.

Various concentrations of the ethanolic extract of Alstonia boonei were prepared to contain between 0.02 to $0.1 \mathrm{mg} / \mathrm{mL}$ of extract in $0.1 \mathrm{M}$ $\mathrm{HCl}$. The absorbance of each concentration was taken at $220 \mathrm{~nm}$ and plotted against the various concentrations to obtain the calibration curve for the extract.

\section{Dissolution Test}

The dissolution times of the tablets were determined at $37 \pm 0.5^{\circ} \mathrm{C}$ in $900 \mathrm{ml}$ of $0.1 \mathrm{M} \mathrm{HCl}$ using a Dissolution Test Apparatus (DA-6D, Veego Scientific Devices Mumbai, India) with the basket rotated at $50 \mathrm{rpm}$. $5 \mathrm{ml}$ samples were withdrawn and replaced with fresh medium at fixed time intervals. The samples were diluted and the amount of drug released was determined spectrophotometrically at $220 \mathrm{~nm}$. Each of the results is the mean of four determinations.

\section{Stability test}

Alstonia boonei tablets were stored at a temperature of $30 \pm 2^{\circ} \mathrm{C}$ and relative humidity of $75 \pm 5 \%$ for a period of twelve (12) months. The mechanical and release properties of the tablets after storage were assessed as earlier described.

\section{Statistical Analysis}

Statistical analysis was carried out using computer software, GraphPad Prism $\AA 4$ (GraphPad Software Inc. San Diego, USA). 
Table 2: Disintegration (DT) and dissolution times $\left(t_{50}, t_{80}\right)$ of Alstonia boonei tablets prepared by direct compression and wet granulation (mean $\pm S D, n=4$ )

\begin{tabular}{|c|c|c|c|c|c|}
\hline \multirow{2}{*}{$\begin{array}{l}\text { Compression } \\
\text { Pressure } \\
\text { (KN) }\end{array}$} & \multicolumn{4}{|c|}{ Direct compression } & \multirow[b]{2}{*}{$\begin{array}{l}t_{80} \\
(\min )\end{array}$} \\
\hline & Diluent & $\begin{array}{l}\text { Drug - } \\
\text { Diluent } \\
\text { Ratio }\end{array}$ & $\begin{array}{c}\text { DT } \\
\text { (min) }\end{array}$ & $\begin{array}{c}\mathbf{t}_{50} \\
(\mathrm{~min})\end{array}$ & \\
\hline 5 & & & $1.47 \pm 0.02$ & $44.66 \pm 0.03$ & $66.89 \pm 0.22$ \\
\hline 10 & & & $2.32 \pm 0.02$ & $46.80 \pm 0.03$ & $72.87 \pm 0.31$ \\
\hline 5 & Lactose & $1: 4$ & $0.30 \pm 0.04$ & $0.50 \pm 0.02$ & $0.70 \pm 0.14$ \\
\hline 10 & & & $0.40 \pm 0.04$ & $0.60 \pm 0.02$ & $0.70 \pm 0.17$ \\
\hline 5 & & $1: 9$ & $0.43 \pm 0.04$ & $0.80 \pm 0.03$ & $0.90 \pm 0.25$ \\
\hline 10 & & & $0.47 \pm 0.03$ & $0.85 \pm 0.02$ & $0.93 \pm 0.21$ \\
\hline 5 & $\begin{array}{l}\text { Avicel }^{\circledR} \\
102\end{array}$ & $1: 4$ & $3.33 \pm 0.04$ & $66.06 \pm 0.04$ & $93.04 \pm 0.22$ \\
\hline $\begin{array}{c}10 \\
5\end{array}$ & & $1: 9$ & $\begin{array}{c}5.77 \pm 0.08 \\
59.83 \pm 0.05\end{array}$ & $\begin{array}{l}80.90 \pm 0.51 \\
97.95 \pm 0.64\end{array}$ & $\begin{array}{l}125.02 \pm 0.24 \\
168.20 \pm 0.14\end{array}$ \\
\hline 10 & & & $79.00 \pm 0.11$ & $120.40 \pm 0.84$ & $182.79 \pm 0.12$ \\
\hline 5 & Emcompress $^{\circledR}$ & $1: 4$ & $0.50 \pm 0.04$ & $1.04 \pm 0.02$ & $10.90 \pm 0.22$ \\
\hline 10 & & & $0.63 \pm 0.04$ & $3.13 \pm 0.04$ & $23.90 \pm 0.17$ \\
\hline 5 & & $1: 9$ & $0.60 \pm 0.06$ & $5.98 \pm 0.34$ & $75.12 \pm 0.24$ \\
\hline 10 & & & $1.17 \pm 0.14$ & $32.11 \pm 0.25$ & $101.01 \pm 0.19$ \\
\hline
\end{tabular}

Wet granulation

\begin{tabular}{|c|c|c|c|c|}
\hline Binder & $\begin{array}{c}\text { Binder } \\
\text { concentration } \\
(\% w / w)\end{array}$ & $\begin{array}{c}\text { DT } \\
\text { (min) }\end{array}$ & $\begin{array}{c}t_{50} \\
(\mathrm{~min})\end{array}$ & $\begin{array}{l}t_{80} \\
(\min )\end{array}$ \\
\hline \multirow[t]{4}{*}{ PVP } & 1 & $1.32 \pm 0.04$ & $14.90 \pm 0.02$ & $76.88 \pm 0.14$ \\
\hline & & $1.60 \pm 0.04$ & $21.00 \pm 0.03$ & $78.79 \pm 0.23$ \\
\hline & 4 & $9.83 \pm 0.02$ & $32.00 \pm 0.04$ & $155.75 \pm 0.24$ \\
\hline & & $10.17 \pm 0.04$ & $15.00 \pm 0.03$ & $162.01 \pm 0.18$ \\
\hline \multirow[t]{4}{*}{ Gelatin } & 1 & $2.35 \pm 0.05$ & $25.00 \pm 0.05$ & $84.96 \pm 0.21$ \\
\hline & & $2.50 \pm 0.06$ & $30.00 \pm 0.02$ & $140.97 \pm 0.17$ \\
\hline & 4 & $4.23 \pm 0.04$ & $26.00 \pm 0.02$ & $89.89 \pm 0.24$ \\
\hline & & $6.17 \pm 0.07$ & $34.00 \pm 0.03$ & $107.88 \pm 0.18$ \\
\hline \multirow[t]{3}{*}{ Corn starch } & 1 & $0.58 \pm 0.02$ & $15.00 \pm 0.04$ & $28.97 \pm 0.14$ \\
\hline & & $0.77 \pm 0.03$ & $15.00 \pm 6.03$ & $32.04 \pm 0.21$ \\
\hline & 4 & $\begin{array}{l}0.75 \pm 0.04 \\
1.07 \pm 0.05\end{array}$ & $\begin{array}{l}12.00 \pm 0.03 \\
15.00 \pm 0.04\end{array}$ & $\begin{array}{l}14.88 \pm 20.11 \\
35.87 \pm 0.21\end{array}$ \\
\hline
\end{tabular}

Tukey-Kramers multiple comparison tests were used to compare the effects of the method of preparation and the excipient/binder on the mechanical and release properties of the tablets. At 95\% confidence interval, $P$ values less than or equal to 0.05 were considered significant.

\section{RESULTS}

The results of the mechanical properties of the $A$. boonei tablets prepared using direct compression and wet granulation are shown in Table 1. The results indicate that CS increased while $\mathrm{F}$ decreased with increase in the compression force. $A$. boonei extract was 
compressible and formed intact tablet without the addition of any diluent. The ranking of crushing strength values for tablets prepared by direct compression was Avicel ${ }^{\circledR}>$ lactose $>$ Emcompress ${ }^{\circledR}$, while the ranking was reversed for friability. The ranking of CS values for tablets prepared by wet granulation was PVP > gelatin > corn starch. The CSFR values also increased with increasing compression force and concentration of diluent/binder employed. The ranking of CSFR values for tablets prepared by direct

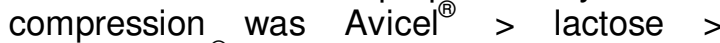
Emcompress $^{\circledR}$, while the ranking was cornstarch > gelatin > PVP for tablets prepared by wet granulation.

The drug release properties of pharmaceutical tablets are characterized by the disintegration and dissolution times. The result of the spectrophotometric analysis shows that the ethanolic extract of $A$. boonei exhibited a principal absorption maximum at $220 \mathrm{~nm}$ typical for alkaloids with an indole chromophore ${ }^{14}$. Thus, the calibration curve to assess the release properties of the tablets were determined at a wavelength of $220 \mathrm{~nm}$ and the linear regression equation for the plot of absorbance versus concentration was given as $y=3.7183 x+0.0007$ with coefficient of determination, $r^{2}=0.997$. The amount of drug released was plotted against time and representative plots for tablets containing the extract alone, Avicel ${ }^{\circledR}$ as direct compression excipient and cornstarch as binder are presented in Fig. 1. The dissolution time $\left(t_{50}\right.$ and $t_{80}$ - time required for $50 \%$ and $80 \%$ of $A$. boonei to be released respectively) were obtained from the dissolution profiles of the tablets. The disintegration and dissolution times of the tablets are shown in Table 2. The ranking of disintegration and dissolution times exhibited by tablets prepared by direct compression was Avicel $^{\circledR}>$ Emcompress $^{\circledR}>$ lactose, while the ranking for tablets prepared by wet granulation was PVP >gelatin > cornstarch.

\section{DISCUSSION}

The mechanical properties of pharmaceutical tablets are important tests for pharmaceutical tablets that often form part of a manufacturer's own specification which are quantifiable by the crushing strength (CS) and the friability $(F)$ of the tablets. The CS provides a measure of tablet strength while $\mathrm{F}$ is a measure of tablet weakness $^{15,16}$. Both parameters indicate the ability of tablets to withstand fracture and abrasion during production and subsequent use $^{15,17}$. The Pharmacopoeial requirements ${ }^{15}$ for the crushing strength is largely dependent on the intended use of the tablet, while for friability, conventional compressed tablets that lose less than $1 \% \mathrm{w} / \mathrm{w}$ of their mass during the friability test are generally considered acceptable $\mathrm{e}^{15,16,18}$. Only tablets prepared using Avicel $^{\circledR}$ as directly compressible excipient passed the test for friability by losing less that $1 \%$ of their weight. This indicates that lactose and Emcompress ${ }^{\circledR}$ at the concentration used appears not suitable for the production of $A$. boonei tablets since the tablets possessed high friability values. Tablets prepared by wet granulation using all the binders on the other hand, showed acceptable CS and F values at the concentrations employed, indicating the suitability of wet granulation method for the production of $A$. boonei tablets. Furthermore, there were statistically significant $(p<0.01)$ differences in the CSFR values of $A$. boonei tablets prepared by both methods. The CSFR values of the tablets prepared wet granulation were significantly $(p<0.01)$ higher than those prepared by direct compression except for formulation containing Avicel®. Thus, the mechanical properties of the tablets were affected by the type and concentration of diluent/binder employed. The differences depended on the type and concentration of excipient and binder employed in the formulation. This result is similar to previous findings ${ }^{18}$.

All formulations of $A$. boonei tablets complied with the official requirement on disintegration (i.e. disintegration within 15 minutes), with the exception of tablets containing high concentration of Avice ${ }^{\circledR}$ which had 


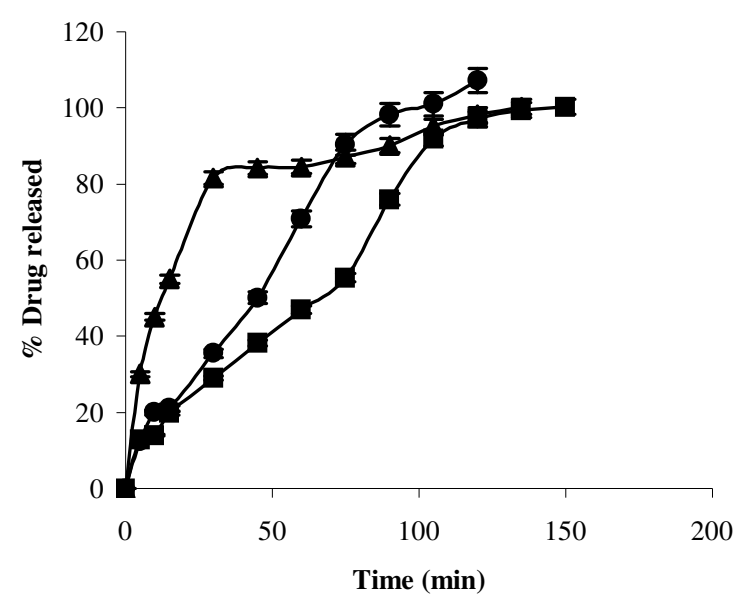

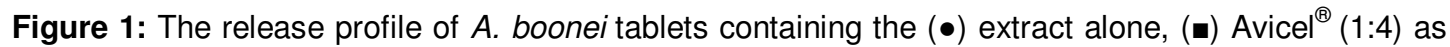
direct compression excipient and $(\boldsymbol{\Lambda}) 1 \% \mathrm{w} / \mathrm{w}$ cornstarch as binder compressed at $5 \mathrm{KN}$ (Error bars $=$ mean $\pm S D$ )

disintegration time greater than 60 minutes. Statistical analysis showed that tablets prepared using $90 \% \mathrm{w} / \mathrm{w}$ Avicel ${ }^{\circledR}$ as excipient had significantly $(p<0.001) \quad$ higher disintegration and dissolution times than those prepared using the other excipients. The dissolution times of the tablets prepared by wet granulation also varied and depended on the type and concentration of the binding agent employed. Tablet prepared by wet granulation did not meet the official requirement on dissolution for uncoated tablets (i.e release of $75 \% \mathrm{w} / \mathrm{w}$ of the active drug within $45 \mathrm{~min})^{15}$ except for tablets prepared using corn starch as binding agent. There were generally significant $(p<0.05)$ differences in the dissolution times of tablets prepared by both methods. Although A. boonei extract alone formed tablets with high bond strength, the tablets however did not meet the requirement on dissolution. This may be due to the absence of other excipient in the formulation. The results indicate the importance of the inclusion of excipients such as disintegrant in the formulation of $A$. boonei tablets.

It is noteworthy that $A$. boonei tablets containing Avicel ${ }^{\circledR}$ which produced tablets of acceptable mechanical properties, however failed to comply with the requirements on dissolution and disintegration. On the other hand, only tablets containing corn starch as binding agent, used in wet granulation, fulfilled the pharmacopoeial requirements on mechanical and drug release properties. Wet granulation appears to produce tablets of acceptable mechanical and drug release properties than those prepared by direct compression. Thus, the methods of preparation of the $A$. boonei tablets need to be carefully selected to ensure the production of tablets with adequate bond strength to withstand the rigors of handling and at the same time release the active compound (s) for biological action. Furthermore, the type and concentration of excipient and binder employed in the formulation of $A$. boonei tablets need to be carefully chosen to enable the production of suitable tablets.

\section{CONCLUSION}

The result obtained shows that the methods of preparation of the $A$. boonei tablets need to be carefully selected to ensure the production of tablets with adequate bond strength to withstand the rigors of handling and at the same time release the active compound (s) for 
biological action. Furthermore, the type and concentration of excipient and binder employed in the formulation of $A$. boonei tablets need to be carefully chosen to enable the production of suitable tablets.

\section{REFERENCES}

1. Irvine FR. The Woody Plants of Ghana, Oxford University Press, London, 1961; pp. 868.

2. Ojewole JAO. Studies on the pharmacology of echitamine, an alkaloid-from the stem bark of Alstonia boonei L. (Apocynaceae). Int. J. Crude Drug Res. 1984; 22: 121-143

3. Iwu MM. Handbook of African Medicinal Plants, CRC Press, Boca Raton, FL, USA. 1993. pp. 116118.

4. Faparusi SI, Bassir O. Triterpines from Alstonia boonei. Phytochemistry, 1972; 21:3083-3084.

5. Oliver-Bever B. Medicinal Plants in Tropical West Africa, Cambridge University Press, London, 1986, pp. 89-90.

6. Asuzu IU, Anaga AO. Pharmacological screening of the aqueous extract of Alstonia boonei stem bark. Fitoter. 1991; 63:411-417.

7. Kweifo-Okai G. Bird D, Field B, Ambrose R, Carroll $A R$, Smith $P$, Valdes $R$. Anti-inflammatory activity of a Ghanaian herbal preparation III. J. Ethnopharmacol. 1995; 46:7-15.

8. Wright CW, Allen D, Phillipson JD, Geoffrey CK, Warhurst DC, Massiot G, Le Men Oliver L. Alstonia species. Are they effective in malaria treatment? J. Ethnopharmacol. 1993; 40: 4145.

9. Vasanth $S$, Gopal RH, Rao RH, Rao RB. Plant antimalarial agents. Ind. J. Sci. Res. 1990; 49:
10. Olajide OA, Awe SO, Makinde, JM, Ekhelar Al, Olusola A, Morebise O, Okpako DT. Studies on the anti-inflammatory, antipyretic and analgesic properties of Alstonia boonei stem bark. $\underline{J}$ Ethnopharmacol_ 2000; 71 (1-2): 179-186.

11. Awe SO, Opeke OO. Effects of Alstonia congensis on Plasmodium berghei berghei in mice. Fitoter. 1990; 61:225-229.

12. Osadebe PO. Antiinflmmatory properties of the root bark of a. boonei. Nig J Nat Prod Med. 2002; 6: 39-41.

13. Gunsel N, Kanig JF. Tablets. In: The Theory and Practice of Industrial Pharmacy, $3^{\text {rd }}$ Ed. ed. by Lachman et al., Lea and Ferbiger, Philadelphia. 1986, pp. $297-303$

14. Vinokurova NG, Zelenkova NF, Baskunov BP, Arinbasarov MU. Determination of Diketopiperazine Alkaloids of the Roquefortine Group by UV Spectroscopy, Thin-Layer Chromatography, and High-Performance Liquid Chromatography. J. Anal Chem, 2001; 56 (3): 258-262.

15. British Pharmacopoeia, 1998. HMSO, London. P. A262.

16. Odeku $O A$, Itiola $O A$, Evaluation of the effects of khaya gum on the mechanical and release properties of paracetamol tablets. Drug Dev. Ind. Pharm 2003; 29 (3): 311-320.

17. Odeku OA, Itiola OA. Evaluation of khaya gum as a binder in a paracetamol tablet formulation. Pharm. Pharmacol. Commun. 1998; 4:183-188.

18. Odeku OA, Fell JT. Effects of the method of preparation on the compression, mechanical, and release properties of khaya gum matrices. Pharm Dev Tech. 2006; 11:435-441. 